\title{
AUTHOR INDEX VOLUME 8 (1990)
}

(The issue number is given in front of the page numbers)

Alemna, A.A., The future of library and information science education in Ghana (Short Communication)

Barron, D.D., The use of distance eduction in United States library and information science: history and current perspectives

(4) $325-339$

Broadbent, M., Information management education: alliances and alignments

Burge, E.J. and J.E. Snow, Interactive audio classrooms: key principles for effective practice

(4) 299-312

Burgess, S.F. and S.E. Edwards, The transformation of library education in Australia

(2) $117-138$

Courrier, Y., Information services in crisis and the post-industrial society

(3) $223-237$

Edwards, R.J., D.H.E. Roberts and M.F. Tunley, Aberystwyth-at a distance

(4) $341-348$

Edwards, S.E., see S.F. Burgess

(2) $117-138$

Farah, B.N., Systems analysis and design course: a project orientation

Jones, A., Providing home computing facilities for students learning at a distance

Menou, M.J. and T. Niang, General programme for training in agricultural information (Short Communication)

(1) $15-22$

(4) $313-324$

Nassimbeni, M., Student learning in a fieldwork programme

(1) $41-43$

Niang, T., see M.J. Menou

Peritz, B.C. and T. Shagam, Continuing education in library and information science: a survey of needs and attitudes in Israel

Roberts, D.H.E., see R.J. Edwards

(1) $97-115$

(1) $41-43$

(1) $23-31$

(4) $341-348$

Shagam, T., see B.C. Peritz

(1) $23-31$

Shoolbred, M., Writing a project: a library user education package for engineering students

Snow, J.E., see E.J. Burge

Thurston, A., Archival training in Europe: dilemmas (Short Communication)

Trickey, K.V., Macros for the production of simple computer-aided instruction packages (Short Communication)

(1) $33-40$

(4) $299-312$

(2) $149-150$

(2) $139-145$

Trickey, K.V., Librans prefer Italian food: an alternative approach to introducing database

Tunley, M.F., see R.J. Edwards

Westley, D., Library training in Denmark: some observations on recent developments (Short Communication)

(3) $239-246$

(4) $341-348$

(2) $145-148$ 